\title{
Estimates of Monoterpene and Isoprene Emissions from the Forests in Switzerland
}

\author{
S. ANDREANI-AKSOYOGLU and J. KELLER \\ Laboratory for Environmental Research and Systems Analysis, Paul Scherrer Institute, \\ CH-5232 Villigen PSI, Switzerland
}

(Received: 23 December 1993; in final form: 18 March 1994)

\begin{abstract}
Emission rates of biogenic volatile organic compounds emitted by the forests were estimated for five geographical regions as well as for all Switzerland. Monoterpene and isoprene emissions rates were calculated for each main tree species separately using the relevant parameters such as temperature, light intensity and leaf biomass density. Biogenic emissions from the forests were found to be about $23 \%$ of the total annual VOC emissions (anthropogenic and biogenic) in Switzerland. The highest emissions are in July and lowest in January. Calculations showed that the coniferous trees are the main sources of the biogenic emissions. The major contribution comes from the Norway spruce (picea abies) forests due to their abundance and high leaf biomass density. Although broad-leaved forests cover $27 \%$ of all the forests in Switzerland, their contribution to the biogenic emissions is only $3 \%$. Monoterpenes are the main species emitted, whereas only $3 \%$ is released as isoprene. The highest emission rates of biogenic VOC are estimated to be in the region of the Alps which has the largest forest coverage in Switzerland and the major part of these forests consists of Norway spruce. The total annual biogenic VOC emission rate of $87 \mathrm{ktonnes} \mathrm{y}^{-1}$ coming from the forests is significantly higher than those from other studies where calculations were carried out by classifying the forests as deciduous and coniferous. The difference is attributed to the high leaf biomass densities of Norway spruce and fir (abies alba) trees which have a strong effect on the results when speciation of trees is taken into account. Besides the annual rate, emission rates were calculated for a specific period during July 4-6, 1991 when a photochemical smog episode was investigated in the Swiss field experiment POLLUMET. Emission rates estimated for that period agree well with those calculated for July using the average temperatures over the last 10 years.
\end{abstract}

Key words: Biogenic emissions, monoterpenes, isoprene, emission inventory, VOC, Norway spruce, fir, Scots pine, larch, oak.

\section{Introduction}

Air pollutants are emitted not only from anthropogenic but also from natural sources. On a global scale, natural emissions often outweigh those from human activities. In developed countries, however, the reverse is generally true, and most of the air pollution comes from fossil fuel burning and other human and industrial activities (Isidorov, 1990). Natural emissions of gases from geogenic and biogenic sources include sulfur and nitrogen compounds, carbon monoxide, methane and nonmethane hydrocarbons (Brasseur and Chatfield, 1991; Warneck, 1988; Keller et al., 1986). Although methane is the most abundant hydrocarbon in the atmosphere, other organic species of biological origin are known to play a more important role 
in the short-term chemistry of the lower atmosphere (Greenberg and Zimmerman, 1984; Trainer et al., 1987; Roselle et al., 1991; Hewitt and Street, 1992).

In the recent years, interest has increased on the question how strongly the physical and chemical properties of the Earth's atmosphere are influenced by emissions from the biosphere and by the uptake of trace gases by biota. Neglecting the natural hydrocarbon emissions in air pollution models leads to inaccurate estimations of pollutant concentrations and to ineffective pollutant reduction strategies based on a reduction of anthropogenic hydrocarbons only (Chameides et al., 1988). For a realistic strategy to reduce the emission of the predominant air pollutants such as sulfur dioxide, nitrogen oxides $\left(\mathrm{NO}_{x}\right)$ and volatile organic compounds (VOC), it is necessary to know the types of the sources as well as their emission rates with some confidence and to predict their future levels.

Although the mixing ratios of the most abundant VOC in unpolluted tropospheric air are much lower than that of methane, their importance is magnified by their high reactivity and by the multitude of the reactions in which they participate. Little is known about their formation and reaction mechanisms. However, there are several attempts to measure and estimate the emission rates of biogenic VOC (Isidorov et al., 1985; Altshuller, 1983; Steinbrecher et al., 1990; Winer et al., 1992).

It is known that plants contain a number of VOC including isoprene, monoand sesquiterpenes, alcohols, aldehydes, ketones, and esters which may be widely distributed throughout plant organs. It appears that these compounds may be important in defense against herbivory (Farentinos et al., 1981). A wide variety of organic compounds, including oxygenated species have been observed as biogenic emissions from vegetation (Altshuller, 1983; Zimmerman et al., 1978; Isidorov et al., 1985). Despite the wide range of volatile compounds emitted, only isoprene and selected monoterpenes have been extensively studied as emission products from vegetation (Killus and Whitten, 1984; Kleindienst et al., 1982; Eichstädter et al., 1993) because of their high reactivity and importance in determining the $\mathrm{OH}$ mixing ratios (Zimmerman et al., 1988).

While both isoprene and terpene emissions are sensitive to temperature, only isoprene emission is strongly affected by the light intensity (Winer et al., 1992; Zimmerman et al., 1988; Corchnoy et al., 1992; Tingey, 1981). However, some evidence has recently shown that $\alpha$-pinene emission from Norway spruce is dependent on light as well as temperature (Schürmann, 1993; Steinbrecher, 1989). Isoprene emission which takes place mainly during daytime, is suggested to be associated with the photosynthetic activities (Delwiche and Sharkey, 1993). It plays an important role on the daytime chemistry of $\mathrm{OH}$ because of its reaction with this radical. Emission rates of terpenes are lower at night than during the daytime due to lower leaf temperature (Zimmerman et al., 1988). Other factors which have been reported to affect the emission of biogenic VOC are plant age (Grinspoon et al., 1991), water deficit and other stresses like air pollution (Hewitt and Street, 1992), 
timber and crop harvesting (Corchnoy et al., 1992; Steinbrecher, 1989), death and decay.

Importance of natural VOC compared to the anthropogenic sources, depends on the forest coverage in a region or country. For instance, in Scandinavian countries, $50 \%$ of the total annual VOC are estimated to come from forests. In OECD-Europe about $30 \%$ of all VOC are estimated to be emitted by forests (Lübkert and Schöpp, 1989).

Conifers are the sources of terpene emissions whereas isoprene is emitted mainly by broad-leaved trees. Coniferous trees such as Norway spruce, fir, and Scots pine are known to emit monoterpenes (Isidorov et al., 1985; Schürmann, 1993). There is some evidence showing that Norway spruce also emits isoprene in addition to monoterpenes (Steinbrecher et al., 1993a). Emissions of various spruce types may differ considerably. Isoprene was reported to be the major species emitted, accounting for approximately 75 and 69 percent of the terpene emissions from Engelmann spruce (picea engelmannii) and Sitka spruce (picea sitchensis), respectively (Evans et al., 1985). However, Steinbrecher et al. (1993a) found that isoprene emission from Norway spruce (picea abies) was only about $10 \%$ of its $\alpha$-pinene emission.

The need for major emission reductions of the predominant air pollutants has been widely accepted by the policymakers of many countries. A significant portion of the total emissions of VOC may come from natural sources. Although there are some attempts to estimate national biogenic hydrocarbon emissions in various countries (Lamb et al., 1987; Anastasi et al., 1991), no detailed study has so far been done in Switzerland. The Swiss Federal Office of Environmental Protection reported the total estimated amount of VOC emitted by natural sources for the year 1983 (BUS, 1987). The forests were classified as coniferous and deciduous. No classification according to the species was done. In this paper, estimations on the emission rates of monoterpenes and isoprene from vegetation in Switzerland are reported. Since forests are the primary vegetative source of biogenic emissions (Novak and Pierce, 1993) and the contribution from the agricultural crops are relatively small in comparison with that from the forest coverage (Lamb et al., 1987), in this study only the emissions from the forests were taken into account in detail.

\section{Methodology}

Three basic parameters are required for developing a biogenic emission inventory (Zimmerman, 1981): Emission factors for the vegetation species, biomass density factors and prevailing conditions such as temperature, season, light, etc. In this work, Switzerland was divided into 5 geographical regions (Figure 1). Biogenic emissions for each region were calculated separately. The basic forest types in each region of Switzerland are given in Table I (Schweizerisches Landesforstinventar, 1988). It is worth noting that the term 'broad-leaved' is not synonymous with 


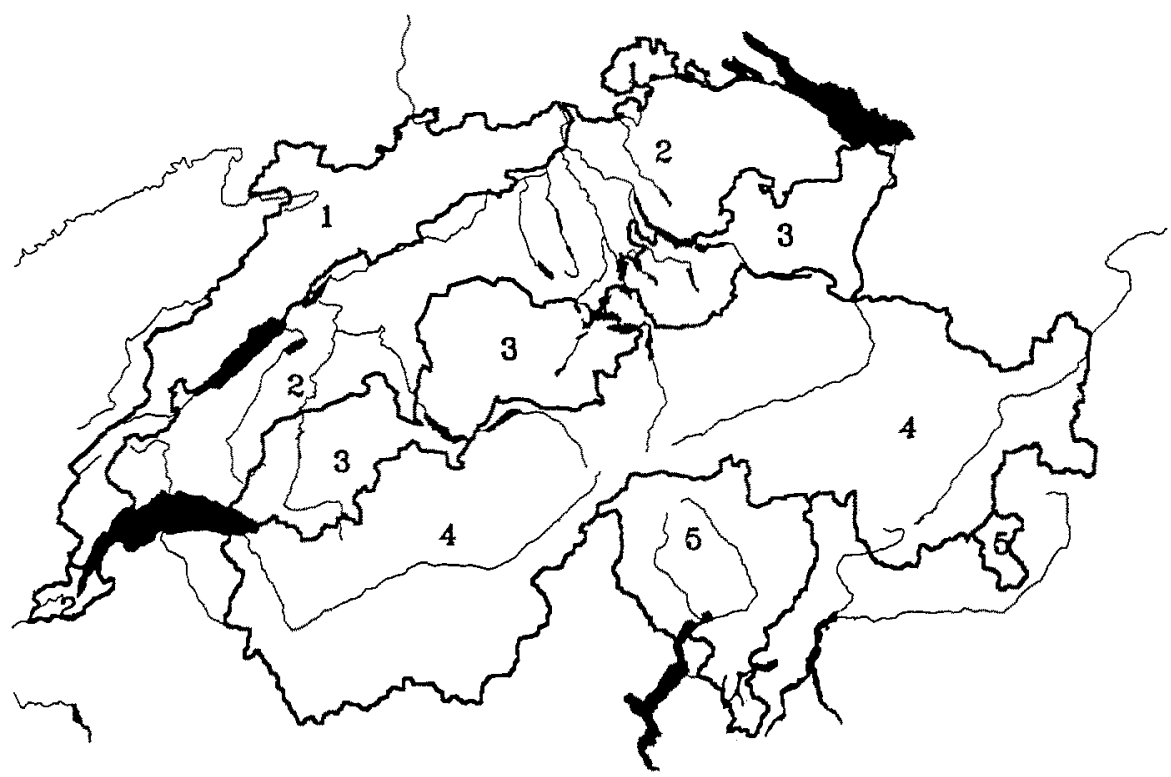

Fig. 1. The five geographical regions of Switzerland. 1: Jura, 2: Swiss Plateau, 3: Prealpine region, 4: the Alps, 5: South of the Alps.

'deciduous', for example larch is a deciduous conifer. Isoprene emission of broadleaved trees was calculated from oak trees, while monoterpene emissions are calculated for Norway spruce, Scots pine, fir and larch. The potential emission of isoprene from Norway spruce was estimated from its $\alpha$-pinene emission rate.

At present, there are only a few emission rate models available. They were derived from the laboratory experiments with various plants (Guenther et al., 1993). Our calculations were based on the emission rate models of Tingey (Tingey et al., 1980; Tingey, 1981) and Schürmann (1993). Tingey's model for isoprene and monoterpene emission rates was derived from the laboratory experiments with oak and slash pine (pinus elliottii) respectively. The isoprene emission rate of oak depends on leaf temperature as well as on photosynthetically active radiation (PAR) according to the following equations:

$$
\begin{aligned}
& \log E_{400}=\frac{0.916}{1+\exp [-0.239(T-29.93)]}+0.845, \\
& \log E_{800}=\frac{3.162}{1+\exp [-0.236(T-22.39)]}-1.097,
\end{aligned}
$$

where:

$E_{400}$ : Emission rate of isoprene for PAR $=400 \mu \mathrm{mol} \mathrm{m}^{-2} \mathrm{~s}^{-1}\left[\mu \mathrm{g} \mathrm{C} \mathrm{dm}^{-2} \mathrm{~h}^{-1}\right]$, $E_{800}$ : Emission rate of isoprene for PAR $=800 \mu \mathrm{mol} \mathrm{m}^{-2} \mathrm{~s}^{-1}\left[\mu \mathrm{g} \mathrm{C} \mathrm{dm}^{-2} \mathrm{~h}^{-1}\right]$, $T$ : leaf temperature $\left[{ }^{\circ} \mathrm{C}\right]$. 
Monoterpene emissions of slash pine were found to depend only on temperature as given by the following equation:

$$
\ln E=-0.332+0.0729 T \text {, }
$$

where:

$E$ : emission rate of terpenes $\left[\mu \mathrm{g} \mathrm{C} \mathrm{g}^{-1} \mathrm{~h}^{-1}\right]$,

$T$ : needle temperature $\left[{ }^{\circ} \mathrm{C}\right]$.

Emission rates of terpenes from Norway spruce were calculated using the data from Schürmann (1993). Schürmann showed that $\alpha$-pinene emission from this species is dependent on the light intensity as well as temperature and gave two types of emission algorithms, in the light and in the dark, for all the individual terpenes emitted from Norway spruce. The algorithms for the sum of all monoterpenes are as follows:

$$
\begin{aligned}
& \ln E_{\mathrm{L}}=23-5324 \cdot T^{-1} \\
& \ln E_{\mathrm{D}}=10-1523 \cdot T^{-1},
\end{aligned}
$$

where:

$E_{\mathrm{L}}$ : emission rate of terpenes in the light $\left[\mathrm{pmol} \mathrm{m}^{-2} \mathrm{~s}^{-1}\right]$,

$E_{\mathrm{D}}$ : emission rate of terpenes in the dark $\left[\mathrm{pmol} \mathrm{m}^{-2} \mathrm{~s}^{-1}\right.$,

$T$ : needle temperature $[\mathrm{K}]$.

These two algorithms were used to calculate the terpene emissions separately during day and night, respectively. As individual terpene emission rates for fir and larch have not been measured, it was assumed that these forests emit like pine-type trees, thus Tingey's model was used. Leaf biomass factors for each tree species in Switzerland were taken from Cannell (1982) and Satoo and Madgwick (1982). For Norway spruce the effect of altitude was taken into account.

Emission rates of the volatile hydrocarbons were calculated in two different ways:

(i) In the first case, annual emissions were calculated using the monthly averaged temperatures over the last 10 years. Temperature data were obtained from the stations of the meteorological network operated by the Swiss Meteorological Institute (SMA). The stations were selected so that their altitudes did not exceed the timberline ( $\sim 2100 \mathrm{~m}$ asl). The number of stations chosen in five regions of Switzerland change between 6 and 17. Average temperature and daylight hours for each region are given in Table II. In the case of isoprene, emissions from the deciduous trees were assumed to take place only during daytime within the period between April and September. A temperature dependent emission rate algorithm for a photosynthetically active radiation (PAR) of $400 \mu \mathrm{mol} \mathrm{m}^{-2} \mathrm{~s}^{-1}$ was applied. For emissions from oak trees, average daytime temperatures in the vegetation period were used. On the 


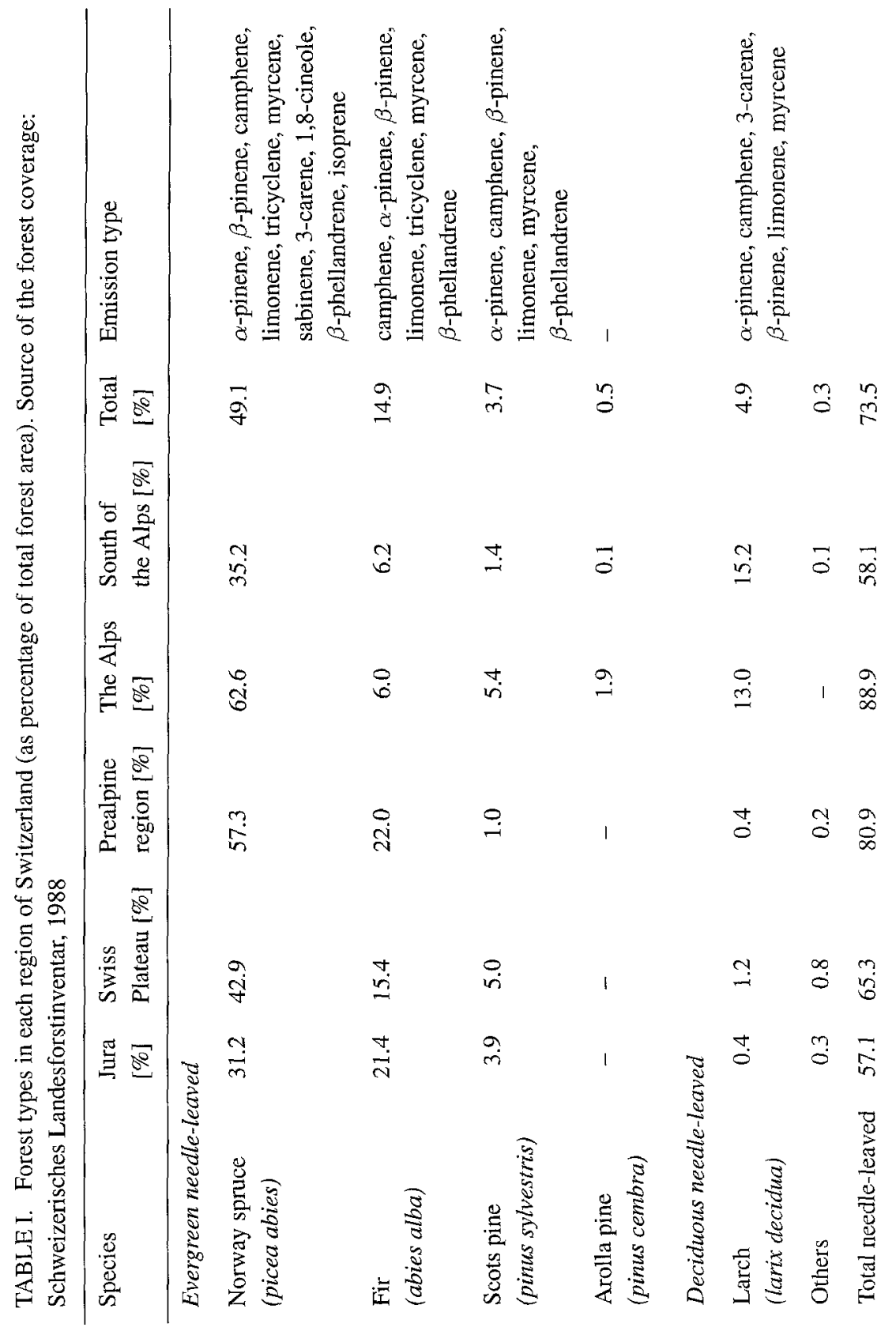




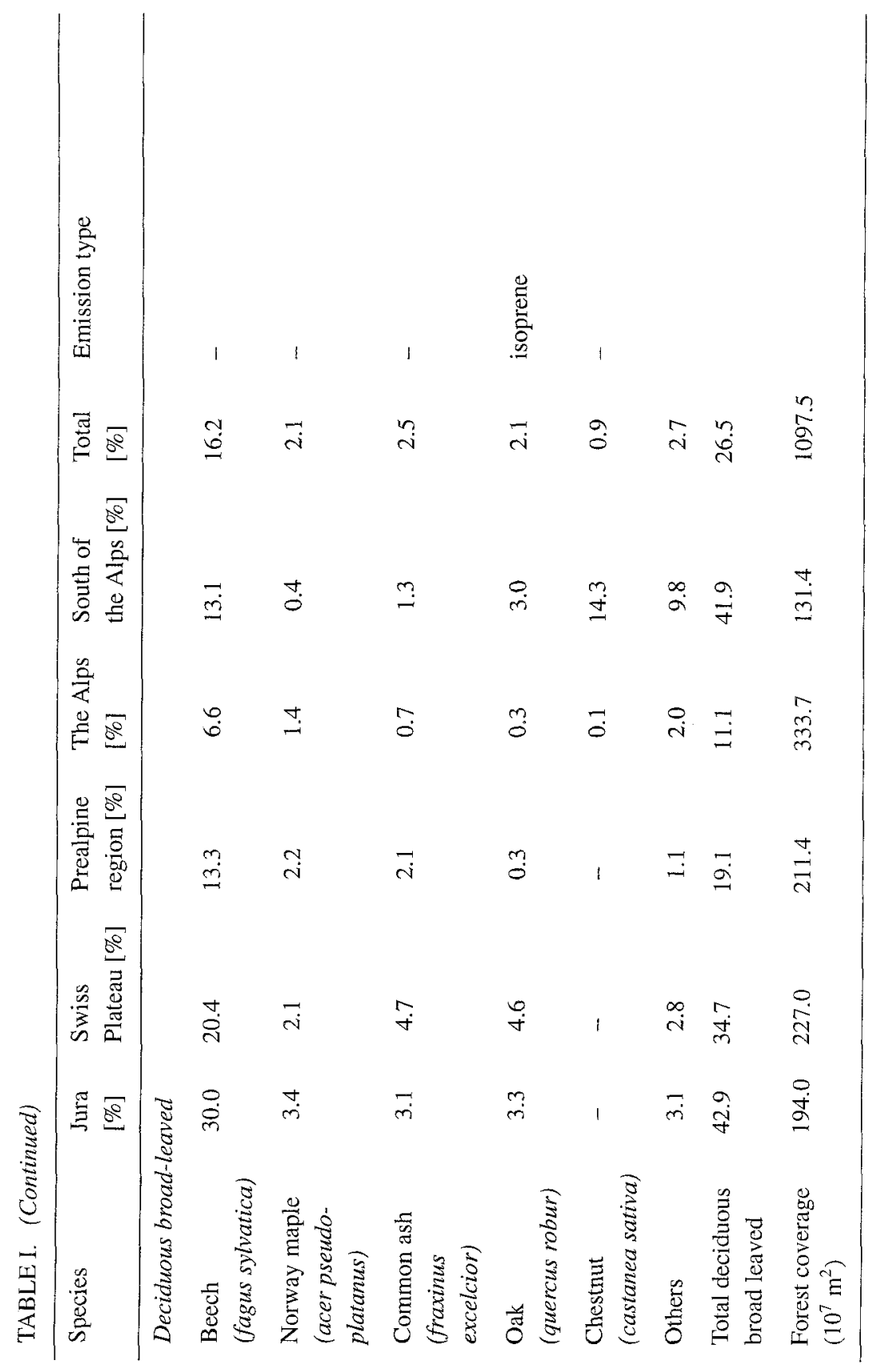


TABLE II. Air temperature and daylight hours averaged over the last 10 years. Source: The Swiss Meteorological Institute (SMA)

\begin{tabular}{lcrrrrrr}
\hline \multirow{2}{*}{ Month } & $\begin{array}{l}\text { Daylight } \\
\text { hours }[\mathrm{h}]^{\mathrm{a}}\end{array}$ & \multicolumn{6}{l}{ Air temperature $\left[{ }^{\circ} \mathrm{C}\right]$} \\
\cline { 3 - 8 } & & & $\begin{array}{l}\text { Jura } \\
\text { Plateau }\end{array}$ & $\begin{array}{l}\text { Prealpine } \\
\text { region }\end{array}$ & The Alps & $\begin{array}{l}\text { South } \\
\text { of the Alps }\end{array}$ & $\begin{array}{l}\text { Switzer- } \\
\text { land }\end{array}$ \\
\hline January & 8.2 & 0.5 & -0.1 & -1.4 & -2.9 & -0.1 & -0.8 \\
February & 9.9 & 1.0 & 0.4 & -1.5 & -2.1 & 0.6 & -0.3 \\
March & 11.7 & 5.1 & 4.6 & 1.6 & 1.9 & 4.4 & 3.5 \\
April & 13.2 & 8.2 & 7.9 & 4.3 & 5.2 & 7.1 & 6.6 \\
May & 14.6 & 12.6 & 12.4 & 8.7 & 9.8 & 11.3 & 11.0 \\
June & 15.5 & 15.6 & 15.4 & 11.4 & 12.5 & 14.7 & 13.9 \\
July & 15.2 & 18.5 & 18.9 & 15.2 & 16.1 & 18.5 & 17.4 \\
August & 13.8 & 18.6 & 18.1 & 14.6 & 15.3 & 17.6 & 16.9 \\
September & 12.2 & 14.9 & 14.6 & 11.6 & 12.1 & 14.1 & 13.5 \\
October & 10.5 & 10.2 & 9.9 & 7.9 & 7.8 & 9.4 & 9.0 \\
November & 8.9 & 4.6 & 4.2 & 2.0 & 1.7 & 3.9 & 3.3 \\
December & 8.0 & 2.0 & 1.6 & 0.2 & -1.5 & 1.2 & 0.7 \\
\hline
\end{tabular}

${ }^{a}$ Time period where the global horizontal irradiance exceeds $10 \mathrm{~W} \mathrm{~m}^{-2}$.

other hand, Norway spruce is expected to emit isoprene all the year during daytime. Monoterpenes from coniferous trees, except larch, were assumed to be released day and night all over the year and calculated using monthly averaged temperatures. In the case of larch only the period between April and September was considered.

(ii) In the second case, hourly temperatures were used to calculate the emission rates for a specific period (July 4-6, 1991) when a photochemical smog episode was investigated in the Swiss field experiment POLLUMET. For isorpene emission factor calculations, PAR was taken as $400 \mu \mathrm{mol} \mathrm{m}{ }^{-2} \mathrm{~s}^{-1}$ between 5:00 and 9:00 am and between 5:00 and 8:00 pm. A PAR value of $800 \mu \mathrm{mol} \mathrm{m}^{-2} \mathrm{~s}^{-1}$ was used between 9:00 am and 5:00 pm. Emission was assumed to reach saturation at PAR values higher than $800 \mu \mathrm{mol} \mathrm{m}^{-2} \mathrm{~s}^{-1}$.

\section{Results and Discussion}

A large fraction of the Swiss forests (74\%) are coniferous, as seen in Table I. Coniferous trees are known to emit mainly monoterpenes such as $\alpha$-pinene, $\beta$ pinene, and others depending on the emitting species (Corchnoy et al., 1992; Janson, 1992; Tingey, 1981). Among the coniferous trees, Norway spruce (picea abies) is the most abundant one (67\%). The main species emitted from these trees are $\alpha$-pinene, $\beta$-pinene, and limonene (Schürmann, 1993). Fir (abies alba) is the second important coniferous species $(20 \%)$. Scots pine (pinus sylvestris) which is reported to emit $\alpha$-pinene, limonene, $\beta$-pinene, $\beta$-phellandrene, and camphene (Janson, 1992), covers about $5 \%$ of the needle-leaved forests in Switzerland. Small 
amounts of pinus mugo arborea and pinus nigra (0.5\%) are also included in this group. The larch (larix decidua, larix kaempferi) is $7 \%$ of all the needle-leaved trees and emits $\alpha$-pinene, $\beta$-pinene, camphene, 3 -carene, limonene, and myrcene. Other coniferous type trees are less than $1 \%$ of all the Swiss forests.

Among the broad-leaved trees, the main species is beech (fagus sylvatica) which covers about $60 \%$ of all the deciduous type trees. The percentages of oak (quercus robur, q. petraea, q. pubescens, q. cerris, q. rubra), ash (fraxinus excelsior, f. ornus), and Norway maple (acer pseudoplatanus, acer platanoides) are all in the same range (8-9\%).

Various studies carried out with oak trees show that the predominant VOC emitted from this species is isoprene (Tingey, 1981; Winer et al., 1992; Rasmussen, 1981; Zimmerman et al., 1988; Altshuller, 1983). However, the area of oak forests in Switzerland is relatively small (2\%). On the other hand, the beech forest which covers about $16 \%$ of the total forest area, and ash, are reported to emit neither isoprene nor terpenes (Hewitt and Street, 1992; Steinbrecher et al., 1993b). The only source for isoprene emission from the deciduous trees is therefore, likely to be the oak forest.

\subsection{ANNUAL EMISSION RATES}

Calculations carried out using the monthly averaged temperatures over the last ten years showed that the highest emission rates take place in July (Figure 2). It is evident from this figure that the major biogenic VOC emitted by the forests are monoterpenes whereas isoprene is only a small fraction of the total emissions.

The leaf biomass densities and the total annual emission rates for each species are shown in Table III. Norway spruce has a high leaf biomass density which varies with altitude (Cannell, 1982). The second highest leaf biomass density is that of fir type trees. The most substantial biogenic VOC emission (27\%) is in the region of the Alps where there is the largest Norway spruce forest coverage. About $24 \%$ of the annual emissions are expected to be in the Swiss Plateau. The amount of biogenic emissions in the regions of Jura and Prealpine are the same, each around $20 \%$. The lowest amount of emissions is in the south of the Alps (10\%).

Norway spruce which covers almost half of the Swiss forests, is the most important species in Switzerland, due to its high biomass density. The second important species is the fir, whose emission is the highest in the region of Jura. Emissions from the Scots pine consist of around 3\% of the total biogenic emissions and the highest emission is in the region of the Alps. Emissions from the deciduous forests (larch and oak) are only $5 \%$ of all the biogenic emissions.

The main species released by the forests are monoterpenes (97\%) whereas the total isoprene emission is only around $3 \%$ of the total biogenic VOC emissions. Oak forests as the main sources of isoprene, are mostly located in the regions of Swiss Plateau, Jura and in the south of the Alps. 


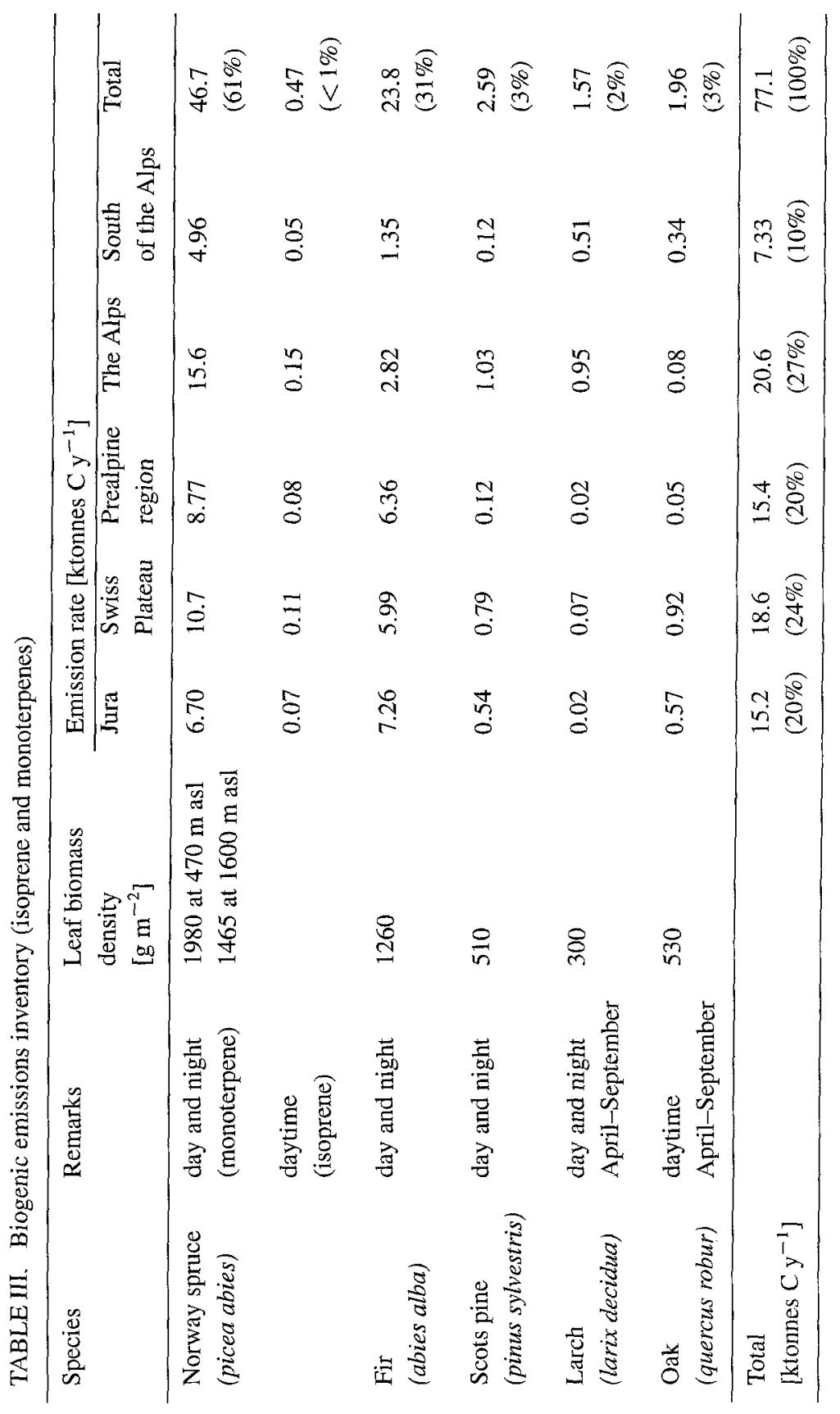




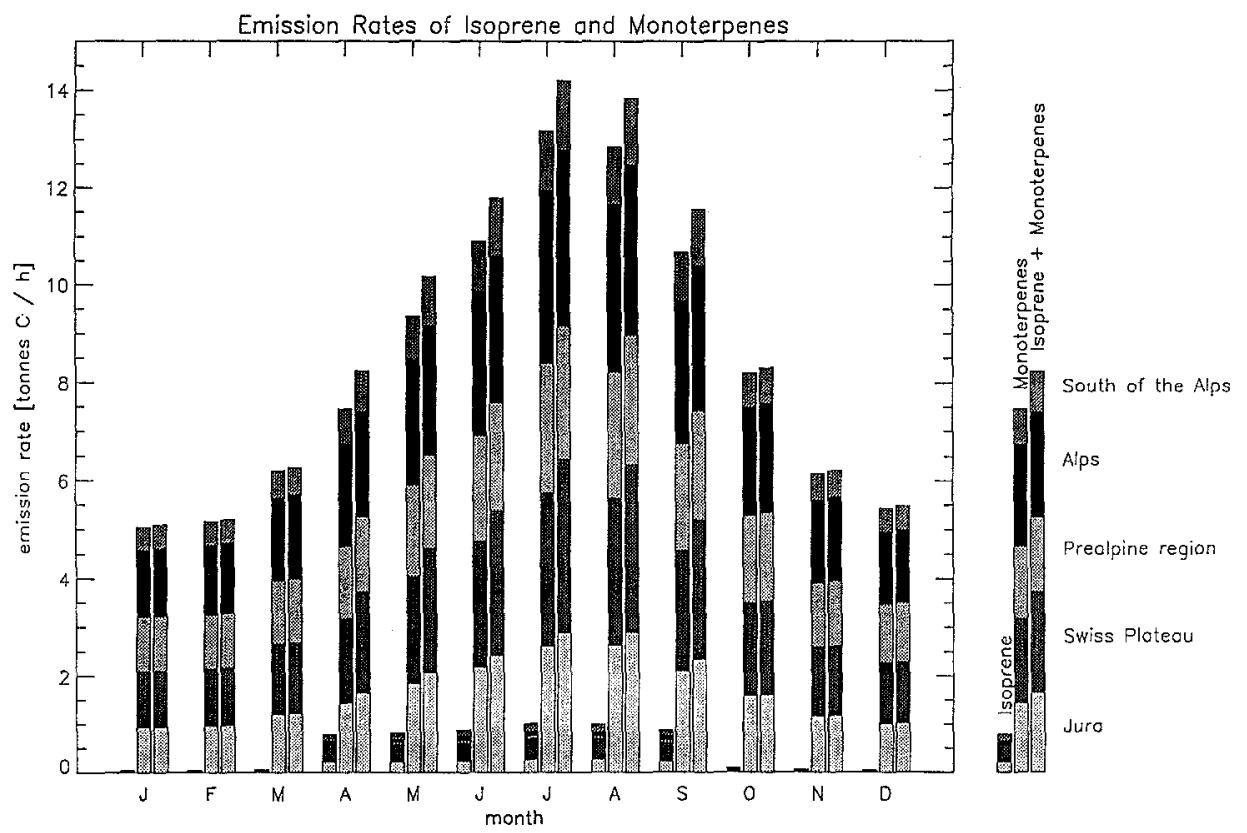

Fig. 2. Emission rates of isoprene and monoterpenes from the forests for the five regions of Switzerland.

The highest monoterpene emission rates are in the region of the Alps which has the largest forest coverage in Switzerland. In addition, about $70 \%$ of the forests in that region is covered by Norway spruce. Norway spruce is therefore, the main source of monoterpene emissions $(63 \%)$. These results are compared with other studies where total biogenic VOC emission estimates for Switzerland were reported (Table IV). In that table the units of our results are given as ktonnes VOC $y^{-1}$ in order to compare with the others. The results of this study suggest that emissions of biogenic volatile organic compounds are significantly higher than the other estimates. The main difference is in the emission from coniferous trees. The speciation of coniferous trees by foliage weight in this work, is most probably the reason of this discrepancy. The high foliage weight of Norway spruce, which covers $49 \%$ of the total forest area of Switzerland, accounts for $63 \%$ of the total monoterpene emissions. The averaged foliage weight values for coniferous trees over large areas, as done in several studies, are dominated by lower values due to pine. The total emission from coniferous and deciduous trees estimated by BUS (1987), Lübkert and Schöpp (1989) and Lübkert and De Tilly (1989) are in a good agreement with each other, since no speciation was done in these cases. The estimation of Andryukov and Timofeev (1989) agrees relatively well with ours. However, we cannot comment on this value since it is not known how the emissions were calculated. 
TABLE IV. Comparison of VOC emission rates for Switzerland [ktonnes VOC $\mathrm{y}^{-1}$ ]

\begin{tabular}{lcccccc} 
& This work & $\begin{array}{l}\text { BUS } \\
(1987)\end{array}$ & $\begin{array}{l}\text { Lübkert } \\
\text { and } \\
\text { Schöppf } \\
(1989)\end{array}$ & $\begin{array}{l}\text { Simpson } \\
(1993)\end{array}$ & $\begin{array}{l}\text { Andryukov } \\
\text { and } \\
\text { Timofeev } \\
(1989)\end{array}$ & $\begin{array}{l}\text { Lübkert } \\
\text { and } \\
\text { de Tilly } \\
(1989)\end{array}$ \\
\hline $\begin{array}{l}\text { From forests } \\
\text { Coniferous }\end{array}$ & 83 & 30 & - & - & - & - \\
Deciduous & 4 & 3 & - & 4 & - & - \\
Total & 87 & 33 & 40 & & 100 & 45 \\
Agricultural land & 0.5 & 2 & - & - & - & - \\
Pasture & 2 & 5.4 & - & - & - & - \\
\hline
\end{tabular}

The calculated biogenic VOC emissions account for about $30 \%$ of anthropogenic emissions estimated for the year 1992 (Roesselet and Kerr, 1993) and represent $23 \%$ of the total VOC. This is much higher than $13 \%$ as reported in BUS (1987), which was calculated by classifying the forests as coniferous and deciduous, without any speciation.

A simple estimation was carried out for the contribution from the pasture and the agricultural crops. Zimmerman (1978) estimated leaf litter and pasture emissions as $162 \mu \mathrm{g} \mathrm{C} \mathrm{m}^{-2} \mathrm{~h}^{-1}$ at $30^{\circ} \mathrm{C}$. The pasture and agricultural areas in Switzerland are about $1.0 \times 10^{10}$ and $3 \times 10^{9} \mathrm{~m}^{2}$, respectively (BUS, 1987). Emission rates of isoprene and monoterpenes were calculated for average temperatures in Switzerland using the mean emission rate and correction factors from Lamb et al. (1993). Emissions from pasture were assumed to take place only for half of the year due to the snow cover and low temperatures in winter. Emissions from the agricultural land were assumed to take place during the period when the crops grow. Our estimations for agricultural land and pasture are lower than those of BUS (1987) probably because the latter includes not only isoprene and monoterpenes, but also other VOC. However, for a detailed inventory it is necessary to calculate the emissions from crops taking the speciation into account, because the emission rates and types differ significantly among the agricultural crops.

\subsection{EMISSION RATES ON JULY 4-6, 1991}

A case study was performed using the temperature and irradiance data measured in Switzerland during the photochemical smog episode from July 4 to July 6, 1991. In all the regions temperatures increased slightly during the 3 days except in the south of the Alps where the daily temperature patterns remained almost the same during this period (Figure 3). Calculated emissions of isoprene and monoterpenes from the forests during the measurement period are shown in Figure 4 for all regions considered. Emission rates are highest in the region of the Alps and in 


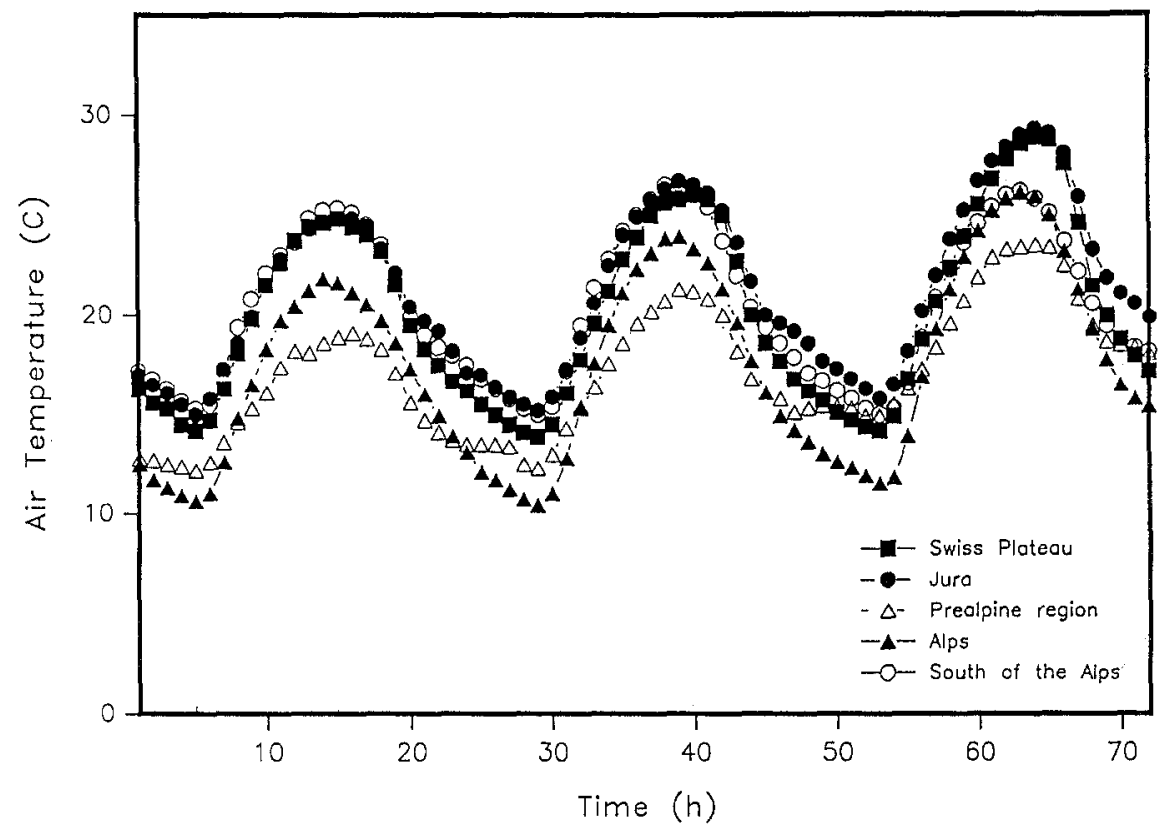

Fig. 3. Variation of air temperature with time in the five regions of Switzerland during July 4-6, 1991.

the Swiss Plateau, and lowest in the south of the Alps due to the different forest coverage. In general, emission rates increased slightly on the 2 nd and the 3 rd day because of temperature increase. The maximum emission rates were between 20 27 tonnes $\mathrm{Ch} \mathrm{h}^{-1}$. The mean emission rates for each region agree quite well with the value obtained for July using the average temperatures over the last 10 years (see Figure 2).

\subsection{UNCERTAINTIES}

Uncertainties in emission inventories are generally high due to several reasons such as emission rates, land use data and lack of relevant measurements. In this work, we used the relevant emission rate algorithm for each species. Assumptions such as spruce type emissions for all kind of spruce trees might lead to inaccurate results, because of the difference in emission types between different picea species. For example, picea engelmannii and picea sitchensis are known to emit mainly isoprene whereas the major species emitted from picea abies are monoterpenes (Evans $e t$ al., 1985; Schürmann, 1993). Using the relevant data for Norway spruce which is the most important species in Switzerland for biogenic emissions, uncertainties were tried to be minimized. However, the data obtained from slash pine had to be used for other types of pine trees such as Scots pine, fir and larch. Emissions from these types of trees are known to be of pine type, but their emission rate algorithms 


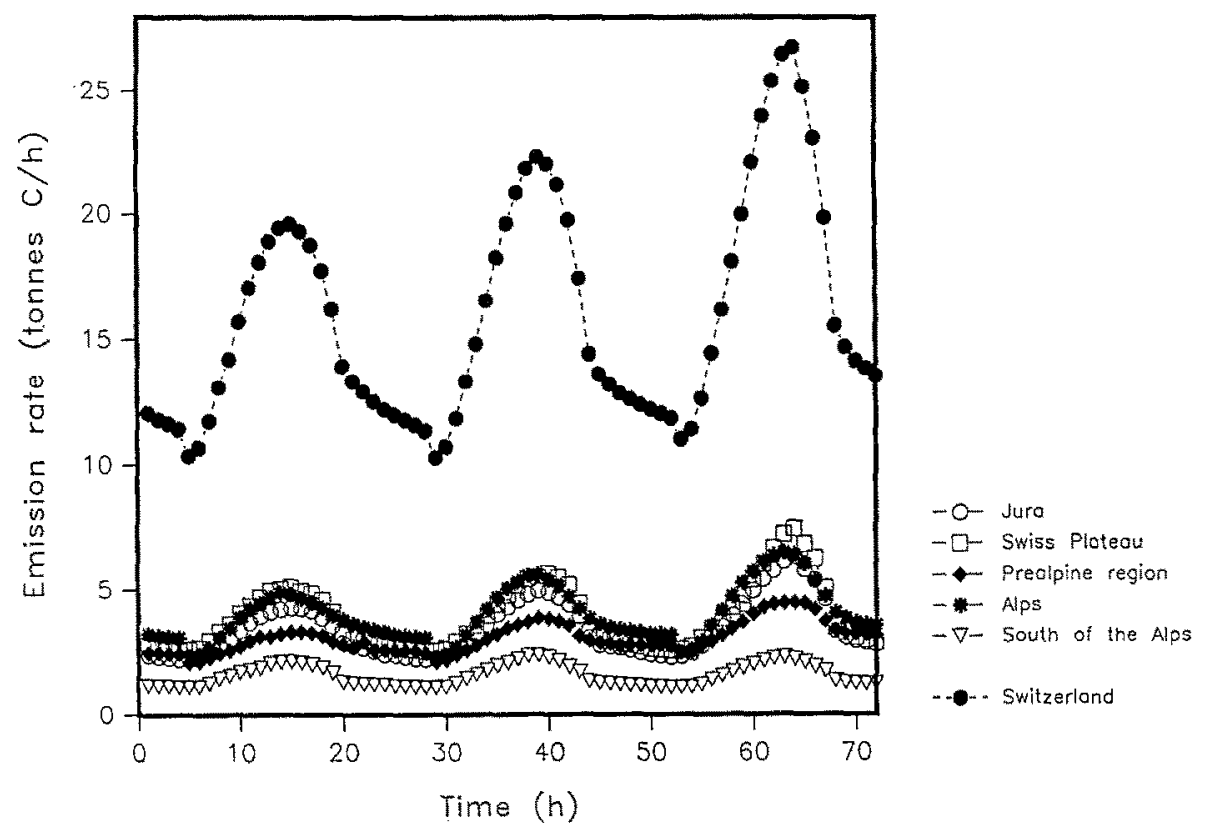

Fig. 4. Diurnal variation of biogenic VOC emission rates (isoprene and monoterpenes) from the forests in the five regions during July 4-6, 1991.

have not yet been measured. Uncertainties in this work might come from the pine type emission rate algorithms used for larch, fir and Scots pine. Isoprene emission of Norway spruce is not yet known well. Further experiments are needed in this field. Although isoprene and monoterpenes are thought to constitute the bulk of the emissions, it has recently become clear that a variety of partially oxidized hydrocarbons are also emitted (Fehsenfeld et al., 1992). However, due to the lack of sufficient information, they were not included in this study.

Another unknown point using the data measured in a temperature range between 20 and $40{ }^{\circ} \mathrm{C}$ for pine and oak, and 10 and $30^{\circ} \mathrm{C}$ for Norway spruce, is the error coming from the extrapolation to lower temperatures. However, this error is assumed to be smail due to the low emission rates at lower temperatures. In order to reduce uncertainties, therefore, emission rate algorithms for each species within a relevant temperature range are required. In general, emission factors calculated for short time periods are more reliable than the extrapolated annual rates because of the large uncertainties involved concerning environmental conditions.

\section{Conclusion}

Biogenic VOC emissions from the forests in Switzerland were calculated using temperature and light dependent emission rate algorithms. Each species known to emit isoprene or monoterpenes, was treated individually, using the corresponding 
emission rate algorithm, leaf biomass density, and forest coverage. Calculations carried out using the monthly averaged temperatures over the last ten years showed that emission rate of biogenic VOC from forests is $87 \mathrm{ktonnes}^{-1}$ and accounts for $23 \%$ of the total VOC emissions in Switzerland. Highest emission rates are found in July. Major sources of the biogenic VOC emissions are the coniferous forests. Emissions from the deciduous forets are only 5\% of all the biogenic emissions. Isoprene emitted by the forests is estimated to be only $3 \%$ of all the emissions. The rest of the emissions are monoterpenes. The highest biogenic VOC emission $(27 \%)$ is in the region of the Alps where there is the largest Norway spruce forest coverage. About $24 \%$ of the annual emissions are expected to be in the Swiss Plateau. Amounts of biogenic emissions in the regions of Jura and Prealpine are the same, each around 20\%. The lowest amount of emissions is in the south of the Alps (10\%). Norway spruce (picea abies) which covers almost half of the Swiss forests, is the most important species of the forests in Switzerland, due to its high biomass density. The second important species is the fir (abies alba), whose emission is the highest in Jura. Emissions from the Scots pine consist of around $3 \%$ of the total biogenic emissions and the highest emission is in the region of the Alps. The larch grows mainly in the region of the Alps and in the south of the Alps. However, its VOC emission is not significant compared to the other species, because it looses the needles during wintertime and its biomass density is relatively low.

It was shown that the speciation is very important because of the biomass density factors. Grouping all the coniferous trees together and using an average biomass value might lead to underestimated emission values. In emission estimation studies, representative leaf biomass values for each species have to be used in order to reduce the uncertainty in such calculations.

\section{Acknowledgements}

We would like to thank The Swiss Meteorological Institute (SMA) for providing us with temperature and irradiance data. Valuable discussions with R. Steinbrecher and comments of P. Zimmerman on the temperature dependence of emissions are gratefully acknowledged. We thank our colleagues at PSI for helpful comments regarding the manuscript.

\section{References}

Altshuller, A. P., 1983, Review: Natural volatile organic substances and their effect on air quality in the United States, Aimos. Environ. 17, No. 11, 2131-2165.

Anastasi, C., Hopkinson, L., and Simpson, V. J., 1991, Natural hydrocarbon emissions in the United Kingdom, Atmos. Environ. 25A, No. 7, 1403-1408.

Andryukov, V. P. and Timofeev, A. B., 1989, Assessment of volatile organic compounds emissions from natural sources in Europe, Contribution to the 4th ECE Task Force on Volatile Organic Compounds, held at Schwetzingen, Federal Republic of Germany, on 30 May-2 June 1989. 
Brasseur, P. G. and Chatfield, R. B., 1991, The fate of biogenic trace gases in the atmosphere, in Sharkey, T. D., Holland, E. A., Mooney, H. A. (eds.), Trace gas emissions, Academic Press Inc., California.

BUS Report, 1987, Emissionen von luftverunreinigenden Stoffen aus natürlichen Quellen in der Schweiz, Schriftenreihe Umweltschutz, Nr. 75, Bundesamt für Umweltschutz (BUS), (since 1988 Bundesamt für Umwelt, Wald und Landwirtschaft, BUWAL) Bern.

Cannell, M. G. R., 1982, World Forest Biomass and Primary Production Data Academic Press Inc., London.

Chameides, W. L., Lindsay, R. W., Richardson, J., and Kiang, C. S., 1988, The role of biogenic hydrocarbons in urban photochemical smog: Atlanta as a case study, Science 241, 1473-1475.

Corchnoy, S. B., Arey, J., and Atkinson, R., 1992, Hydrocarbon emissions from twelve urban shade trees of the Los Angeles, California Air Basin, Atmos. Environ. 26B, 339-348.

Delwiche, C. F. and Sharkey, T. D., 1993, Rapid appearance of ${ }^{13} \mathrm{C}$ in biogenic isoprene when ${ }^{1.3} \mathrm{CO}_{2}$ is fed to intact leaves, Plant, Cell and Environment 16, 587-591.

Eichstädter, G., Schürmann, W., Steinbrecher, R., and Ziegler, H., 1993, Diurnal cycles of soil and needle monoterpene emission rates and simultaneous gradient measurements of monoterpene concentrations in the stem region and above a Norway spruce canopy, in Borell, P. M. et al, (eds.), Proceedings of EUROTRAC Symposium '92, SPB Academic Publishing, The Hague.

Evans, R. C., Tingey, D. T., and Gumpertz, M. L., 1985, Interspecies variation in terpenoid emissions from Engelmann and Sitka spruce seedlings, Forest Sci. 31, 132-142.

Farentinos, R. C., Capretta, P. J., Kepner, R. E., and Littlefield, V. M., 1981, Selective herbivory in Tassel-Eared Squirrels: Role of monoterpenes in Ponderosa pines chosen as feeding trees, Science 213, 1273-1275.

Fehsenfeld, F., Calvert, J., Fall, R., Goldan, P., Guenther, A., Hewitt, N. C., Lamb, B., Liu, S., Trainer, M., Westberg, H., Zimmerman, P., 1992, Emissions of volatile organic compounds from vegetation and the implications for atmospheric chemistry, Global Biogeochemical Cycles 6 , No. $4,389-430$.

Greenberg, J. P. and Zimmermann, P. R., 1984, Non-methane hydrocarbons in remote tropical, continental and marine atmospheres, J. Geophys. Res. 89, 4767-4778.

Grinspoon, J., Bowman, W. D., and Fall, R., 1991, Delayed onset of isoprene emission in developing Velvet Bean (Mucuna sp.) leaves, Plant Physiol. 97, 170-174.

Guenther, A. B., Zimmerman, P. R., Harley, P. C., Monson, R. K., and Fall, R., 1993, Isoprene and monoterpene emission rate variability: Model evaluations and sensitivity analyses, J. Geophys. Res. 98, D7, 12609-12617.

Hewitt, C. N. and Street, R. A., 1992, A qualitative assessment of the emission of non-methane hydrocarbon compounds from the biosphere to the atmosphere in the United Kingdom: Present knowledge and uncertainties, Atmos. Environ. 26A, 3069-3077.

Isidorov, V. A., Zenkevich, I. G., and Ioffe, B. V., 1985, Volatile organic compounds in the atmosphere of forests, Atmos. Environ. 19, 1-8.

Isidorov, V. A., 1990, Organic Chemistry of the Earth's Atmosphere, Springer-Verlag Berlin, Heidelberg.

Janson, R., 1992, Monoterpene concentrations in and above a forest of Scots pine, J. Atmos. Chem. 14, 385-394.

Keller, M., Kaplan, W., and Wofsy, S. C., 1986, Emissions of $\mathrm{N}_{2} \mathrm{O}, \mathrm{CH}_{4}$ and $\mathrm{CO}_{2}$ from tropical forest soils, J. Geophys. Res. 91, 11791-11802.

Killus, J. P. and Whitten, G. Z., 1984, Isoprene: A photochemical kinetic mechanism, Environ. Sci. Technol. 18, 142-148.

Kleindienst, T. E., Harris, G. W., and Pitts, J. N., 1982, Rates and temperature dependences of the reaction of $\mathrm{OH}$ with isoprene, its oxidation products and selected terpenes, Environ. Sci. Technol. 16, 844-846.

Lamb, B., Günther, A., Gay, D., and Westberg, H., 1987, A national inventory of biogenic hydrocarbon emissions, Atmos. Environ. 21, No. 8, 1695-1705.

Lamb, R., Gay, D., Westberg, H., and Pierce, T., 1993, A biogenic hydrocarbon emission inventory for the U.S.A. using a simple forest canopy model, Atmos. Environ. 27A, No. 11, 1673-1690. 
Lübkert, B., and Schöpp, W., 1989, A model to calculate natural VOC emissions from forests in Europe, Working Paper, WP-89-082, International Institute for Applied Systems Analysis.

Lübkert, B. and De Tilly, S., 1989, The OECD map emission inventory for $\mathrm{SO}_{2}, \mathrm{NO}_{x}$ and VOC in Western Europe, Atmos, Environ. 23, No. 1, 3-15.

Novak, J. H. and Pierce, T. E., 1993, Natural emissions of oxidant precursors, Water, Air and Soil Pollution 67, 57-77.

Rasmussen, R. A., 1981, A review of the natural hydrocarbon issue, in Bufalini, J. J. and Arnts, R. R. (eds.), Atmospheric Biogenic Hydrocarbons I, Ann Arbor Science, Ann Arbor, MI.

Roesselet, C. M. and Kerr, J. A., 1993, Photochemical Modelling of Photo-oxidant Levels over the Swiss Plateau and Emission Reduction Scenarios, PSI Bericht Nr. 93-03.

Roselle, S. J., Pierce, T. E., and Schere, K. L., 1991, The sensitivity of regional ozone modelling to biogenic hydrocarbons, J. Geophys. Res. 96, 7371-7394.

Satoo, T. and Madgwick, H. A. I., 1982, Forest Biomass, Martinus Nijhoff/Dr. W. Junk Publishers, The Hague.

Schürmann, W., 1993, Emission von Monoterpenen aus Nadeln von Picea Abies (L.) Karst, sowie deren Verhalten in der Atmosphäre, Ph.D. Thesis, Technische Universität München.

Schweizerisches Landesforstinventar, 1988, Report No. 305, Birmensdorf.

Simpson, D., 1993, Photochemical model calculations over Europe for two extended summer periods: 1985 and 1989. Model results and comparison with observations. Atmos. Environ. 27A, 921-943.

Steinbrecher, R., 1989, Gehalt und Emission von Monoterpenen in oberirdischen Organen von Picea Abies [L] Karst, Ph.D. Thesis, Technische Universität München.

Steinbrecher, R., Schürmann, W., Schönwitz, R., Eichstädter, G., and Ziegler, H., 1990, Volatile monoterpenes in a forest of spruce (Picea Abies [L] Karst.): Sources and mechanisms of emission and behavior in the atmosphere, in Borrell, P. M. et al., The Proceedings of EUROTRAC Symposium '90, 205-208.

Steinbrecher, R., Karbach, I., Nitz, S., and Ziegler, H., 1993a, Isoprene emission from Norway spruce and behavior in the atmosphere of a mature stand, in Borrell, P. M. et al. (eds.), The Proceedings of EUROTRAC Symposium '92, 293-295.

Steinbrecher, R., Schürmann, W., Schreiner, A. M., Ziegler, H., 1993b, Terpenoid emissions from common oak (quercus robur L.) and Norway spruce (picea abies L. Karst.), Proceedings of the CEC/BIATEX Workshop, 4-7 May, 1993, Averio.

Tingey, D. T., Manning, M., Grothaus, L. C., Burns, W. F., 1980, Influence of light and temperature on monoterpene emission rates from slash pine, Plant Physiol. 65, 797-801.

Tingey, D. T., 1981, The effect of environmental factors on the emissiosn of biogenic hydrocarbons from live oak and slash pine, in Bufalini, J. J. and Arnts, R. R. (eds), Atmospheric Biogenic Hydrocarbons I, Ann Arbor Science, Ann Arbor, MI.

Trainer, M., Williams, E. J., Parrish, D. D., Buhr, M. P., Allwine, E. J., Westberg, H. H., Fehsenfeld, F. C., and Liu, S. C., 1987, Models and observations of the impact of natural hydrocarbons on rural ozone, Nature 329, 705-707.

Warneck, P., 1988, Chemistry of the Natural Atmosphere, Academic Press Inc., California.

Winer, A. M., Arey, J., Atkinson, R., Aschmann, S. M., Long, W. D., Morrison, C. L., and Olszyk, D. M., 1992, Emission rates of organics from vegetation in California's Central Valley, Atmos. Environ. 26A, 2647-2659.

Zimmerman, P. R., Chatfield, R. B., Fishman, J., Crutzen, P. J., and Hanst, P. L., 1978, Estimates on the production of $\mathrm{CO}$ and $\mathrm{H}_{2}$ from the oxidation of hydrocarbon emissions from vegetation, Geophys. Res. Lett. 5, 679-682.

Zimmerman, P. R., 1981, Testing of hydrocarbon emissions from vegetation and methodology for compiling biogenic emission inventories, in Bufalini, J. J. and Arnts, R. R. (eds.), Atmospheric Biogenic Hydrocarbons, Ann Arbor Science, Ann Arbor, MI.

Zimmerman, P. R., Greenberg, J. P., and Westberg, C. E., 1988, Measurements of atmospheric hydrocarbons and biogenic emission fluxes in the Amazon boundary layer, J. Geophys. Res. 93, $1407-1416$. 